\title{
The metabolism of circulating non-esterified fatty acids by the whole animal, hind-limb muscle and uterus of pregnant ewes
}

\author{
BY D. W. PETHICK*, D. B. LINDSAY, P. J. BARKER AND \\ A. J. NORTHROP \\ Biochemistry Department, ARC Institute of Animal Physiology, Babraham, \\ Cambridge CB2 $4 A T$
}

(Received 19 March 1982-Accepted 17 August 1982)

1. The over-all and regional metabolism of non-esterified fatty acids (NEFA) was studied using a combination of isotopic and arteriovenous-difference techniques.

2. There was a common linear relationship, whether stearic, palmitic or oleic acids were used as tracer, between the arterial NEFA concentration and the rates of entry and oxidation.

3. Assuming that the tracer used reflected the metabolism of all the NEFA, the total entry rate in fed and fasted pregnant ewes was (mean $\pm \mathrm{SE}$ ) $0.44 \pm 0.02$ and $0.55 \pm 0.07 \mathrm{mmol} / \mathrm{h}$ per $\mathrm{kg}$ body-weight respectively. Oxidation of NEFA contributed (mean $\pm \mathrm{SE}$ ) $34 \pm 5$ and $58 \pm 7 \%$ to the respiratory carbon dioxide in fed and fasted animals, this accounting for (mean $\pm \mathrm{SE}$ ) $46 \pm 6$ and $59 \pm 3 \%$ of the respective entry rates.

4. Hind-limb muscle both utilized and produced NEFA. The mean gross fractional extraction (calculated from isotopic uptake) was (mean $\pm \mathrm{SE}$ ) $9 \pm 1 \%$. Gross utilization of any NEFA and appearance of ${ }^{14} \mathrm{CO}_{2}$ across the muscle were linearly related to the arterial concentration of tracer fatty acid, irrespective of whether this was oleate or stearate. The amount of ${ }^{14} \mathrm{CO}_{2}$ appearing was consistent with (mean $\pm \mathrm{SE}$ ) $54 \pm 8 \%$ of the $\mathrm{CO}_{2}$ produced by the hind-limb being derived from NEFA oxidation.

5. Infused NEFA were partly converted to ketone bodies. Uptake and oxidation in the hind-limb of ketones formed in the liver could account for approximately $20 \%$ of the ${ }^{14} \mathrm{CO}_{2}$ apparently produced in muscle from NEFA. Correction for this reduces the proportion of $\mathrm{CO}_{2}$ derived from NEFA to $43 \%$. There was some indication that ketones were also produced from NEFA in the hind-limb.

6. NEFA were not a significant energy source for the gravid uterus.

7. An over-all view of energy sources for the whole animal and for hind-limb muscle in normal and fasted pregnant sheep was presented.

When animals rely on their tissue reserves at least $80 \%$ of the energy expenditure is derived from fat (Blaxter, 1962) but the form by which fat is transported and oxidized is not well established. Initially, at least, fat is transported from the depots as non-esterified fatty acids (NEFA). Lindsay (1975) summarized much of the work in which NEFA entry rate and oxidation has been measured in sheep and other species. Apparently approximately $35 \%$ of the respiratory carbon dioxide was derived from NEFA. Moreover, Pethick \& Lindsay $\left(1982 c\right.$ ) have recently assessed the contribution of ketone bodies to $\mathrm{CO}_{2}$ in fasted pregnant ewes as approximately $30 \%$. Since ketone bodies are largely synthesized from NEFA, it is possible that most NEFA oxidation occurs via ketone-body formation rather than directly and that there are additional means by which fat is oxidized. Few studies of NEFA metabolism, however, have been made in fasted pregnant ewes, although Leat \& Ford (1966) did show in two such animals that only $40 \%$ of palmitic acid flux was promptly oxidized.

Most tissues can utilize fatty acids directly as an energy source. Zierler (1976) reviewed the utilization of fatty acids by skeletal and cardiac muscle of non-ruminants as determined by arteriovenous-difference techniques. Isotopic techniques are necessary because a simultaneous uptake and output of NEFA has been demonstrated in studies with the human forearm (Friedberg et al. 1960), human leg (Havel et al. 1967), dog hind-limb (Spitzer \& Gold, 1964) and bovine hind-limb (Bell \& Thompson, 1979). No comparable studies have been made with sheep.

* Present address; School of Veterinary Science, Murdoch University, W. Australia. 
In this study, the measurements of NEFA entry rate and hind-limb and uterine utilization are reported for pregnant sheep. The experiments were planned to determine (1) if the metabolisms of individual NEFA were similar, (2) the contribution of NEFA to the whole-animal energy metabolism, (3) the contribution of NEFA to the energy metabolisms of hind-limb and gravid uterus, (4) the possible role of ketones in the catabolism of NEFA, (5) to what extent the total and hind-limb energy metabolisms can be accounted for in terms of known substrates. A preliminary account of some of this work has been given (Pethick \& Lindsay, 1982a).

\section{MATERIALS AND METHODS}

\section{Experimental animals and design of experiments}

Pregnant Clun Forest ewes, 3-4 years old, were housed singly in pens for 6-7 weeks before lambing and given $1 \mathrm{~kg}$ chopped hay ( $500 \mathrm{~g}$ lucerne (Medicago sativa), $500 \mathrm{~g}$ cocksfoot (Dactylis glomerata)) and $100 \mathrm{~g}$ concentrates at 09.00 hours and a further $100 \mathrm{~g}$ concentrates at 16.00 hours. The concentrate was a pelleted mixture by relative weight: ground barley $0 \cdot 59$, flaked maize $0 \cdot 1$, rolled oats $0 \cdot 1$, soyabean meal $0 \cdot 1$, molassine meal 0.1 plus a supplement of vitamins and minerals. About 2 weeks before lambing the concentrate intake was doubled. Animals were surgically prepared with carotid arterial and jugular, uterine and recurrent tarsal venous catheters as described by Pethick \& Lindsay (1982c). Catheters were inserted under general anaesthesia at least $7 \mathrm{~d}$ before experiments, except for the tarsal venous catheters which were inserted under local anaesthesia $24 \mathrm{~h}$ before experiments and removed immediately after the completion of experiments in order to minimize thrombosis.

In experiments in which uptakes of glucose, lactate and acetate by uterus and hind-limb muscle were determined, seventeen sheep were fasted for 3-4 $\mathrm{d}$ and five paired or triplet (six sheep) arterial and venous blood samples were taken by syringe from the catheters of the ewes while they were housed in their normal individual pens, the sampling being between 09.00 and 17.00 hours. For infusion experiments, sheep (mean weight $80 \mathrm{~kg}$, 120-130 d pregnant) were placed in an open-circuit calorimeter (Neill et al. 1979) with their heads enclosed in a hood to which they had previously been acclimatized for at least two 6-h periods. Eight animals, fasted for 3-4 d, were used in these studies. For experiments designated ' $f e d$ ', three additional animals were used in which the normal ration was made available approximately $2 \mathrm{~h}$ before infusions began. Any food not eaten initially was made available by being placed in the hood at intervals, the animals having previously been accustomed to this procedure. The calorimeter allowed measurement of ${ }^{14} \mathrm{CO}_{2}$ radioactivity in expired air in addition to respiratory gas exchange. Approximately $1 \mathrm{~h}$ after the animal's head had been placed in the hood, $\simeq 60 \mu \mathrm{Ci}\left[1-{ }^{14} \mathrm{C}\right]$-labelled fatty acid (palmitic, stearic or oleic acids) was infused intrajugularly for approximately $5 \mathrm{~h}$. From the beginning of infusion, blood samples were taken hourly over $10-12 \mathrm{~h}$, by syringe, from carotid, uterine and tarsal catheters. Ethylene diamine tetra-acetic acid $(1 \mathrm{mg} / \mathrm{ml}$ blood $)$ was added immediately. $\mathrm{CO}_{2}$ and ${ }^{14} \mathrm{CO}_{2}$ were determined on the day of experiment by the method of Hinks et al. (1966). A further portion of blood was frozen $\left(-20^{\circ}\right)$ and used for other analyses within 1 month. Plasma was separated from the remainder, frozen $\left(-80^{\circ}\right)$ and used within $24 \mathrm{~h}$ for NEFA analysis.

Muscle blood flow was determined after the last blood sample was taken, as described by Pethick et al. (1981).

\section{Laboratory procedures}

$\left[1-{ }^{14} \mathrm{C}\right]$-Labelled fatty acids were obtained in hexane with specific radioactivity (SR) greater than $50 \mathrm{mCi} / \mathrm{mmol}$ (Radiochemical Centre, Amersham). The fatty acids were prepared for infusion immediately before the experiment essentially as described by Lindsay \& Leat (1977). 
Plasma NEFA concentration and SR were determined by a modification of the gas-liquid chromatographic technique described by De Vries et al. (1976). Plasma (1 ml) was mixed with $6 \mathrm{ml}$ Dole reagent (Dole, 1956) at $0^{\circ}$. To this mixture was added $1 \mathrm{ml}$ water and $2 \mathrm{ml}$ heptane. After shaking well, the heptane phase was removed into a new tube, the residual phase being re-extracted with a further $2 \mathrm{ml}$ heptane. The pooled heptane fractions were then extracted three times with $1 \mathrm{ml}$ alcoholic potassium carbonate $(60 \mathrm{ml}$ ethanol, $0.4 \mathrm{ml}$ amyl alcohol, $33 \mathrm{ml} \mathrm{K} \mathrm{CO}_{3}(40 \mathrm{~g} / \mathrm{l})$, distilled water to $\left.100 \mathrm{ml}\right)$ and the lower phase collected. The aqueous phase containing NEFA as potassium soaps was washed twice with $2 \mathrm{ml}$ heptane. NEFA were extracted back into heptane by adding three drops of $13 \mathrm{M}$ sulphuric acid and $2 \mathrm{ml}$ heptane and extracting twice more with $1 \mathrm{ml}$ heptane. The final pooled heptane extract was evaporated to dryness under nitrogen at $40^{\circ}$. For analysis, the NEFA were dissolved in $100 \mu \mathrm{l}$ heptane, triplicate $1 \mu \mathrm{l}$ samples being injected onto a $2 \mathrm{~m} \times 4$ mm glass column packed with 10\% SP216-PS on 100-110 mesh Supelcoport (Chromatography Services, Merseyside) in a Pye 104 gas-liquid chromatograph. Molar proportions and total NEFA were determined using pentadecanoic acid, this being added at the initial extraction stage. The remainder of the sample was used for radioactivity determination, essentially as described by Pethick et al. (1981) for acetate. Calculation of the SR of circulating NEFA assumed there was no interconversion of plasma NEFA within the period of experiment.

The concentration and SR of ketones and other metabolites were determined as described by Pethick et al. (1981) and Pethick \& Lindsay (1982c).

\section{Whole animal}

\section{Calculations}

(a) Entry rate $(\mathrm{mmol} / \mathrm{h})$

$$
=\frac{I}{\mathrm{NEFA}_{\mathrm{SR}}}
$$

where $I$ is the infusion rate (disintegrations/min per h) of $\left[1-{ }^{14} \mathrm{C}\right]$-labelled fatty acids (palmitic, oleic or stearic) and $\mathrm{NEFA}_{\mathrm{SR}}$ is the mean arterial specific radioactivity of NEFA when this is no longer time-dependent, that is, after about $1 \mathrm{~h}$ of infusion.

(b) Fraction of respiratory $\mathrm{CO}_{2}$ derived from individual NEFA

$$
=\frac{\text { terminal expired }\left({ }^{14} \mathrm{CO}_{2}\right)_{\mathrm{SR}}}{\text { plateau arterial } \mathrm{NEFA} A_{\mathrm{SR}}} \text {, }
$$

where SRs are expressed as disintegrations/min per mAtom $\mathrm{C}$. The terminal expired $\left({ }^{14} \mathrm{CO}_{2}\right)_{\mathrm{SR}}$ calculated by fitting the experimental values for $\left({ }^{14} \mathrm{CO}_{2}\right)_{\mathrm{SR}}$ obtained during the infusion to a power equation, $y=\mathrm{A}+\mathrm{B} . \mathrm{R}^{t}$ where $y$ is the $\mathrm{SR}$ at time $t$ in hours, $\mathrm{A}, \mathrm{B}$ and $\mathrm{R}$ being empirical constants (Snedecor \& Cochran, 1967). This technique is superior to the more usual equation $y=\mathrm{A}\left(1-\mathrm{e}^{-\mathrm{k} t}\right)$ because it is not constrained to pass through the point of origin $(0,0)$ and there is frequently a lag period before the SR begins to increase.

(c) Proportion of ketone bodies derived from NEFA

$$
=\frac{S R \text { arterial } D(-) 3 \text {-hydroxybutyrate at end of infusion }}{S R \text { arterial (total) NEFA at end of infusion }}
$$

Both values are expressed as disintegrations/min per mAtom C. The SR of arterial (total) NEFA is calculated as the ratio disintegrations/min per l plasma:total NEFA concentration. This calculation assumes that (i) the SR of total ketones is the same as the SR of $D(-) 3$-hydroxybutyrate, (ii) the tracer NEFA is representative of total NEFA, (iii) the various NEFA contribute equally to ketogenesis and (iv) an equilibrium arterial $D(-) 3-$ hydroxybutyrate $S R$ has been reached by the end of the tracer infusion. 
Tissues

(a) Net fractional extraction of NEFA $=(A-V) / A$, where $A$ and $V$ are the concentrations of NEFA (mM) in arterial and venous plasma, respectively.

(b) Gross fractional extraction of NEFA

$$
=\frac{\left({ }^{14} \mathrm{C}_{A}-{ }^{14} \mathrm{C}_{V}\right)}{\left({ }^{14} \mathrm{C}_{A}\right)}
$$

where ${ }^{14} \mathrm{C}_{A}$ and ${ }^{14} \mathrm{C}_{V}$ are the amounts of radioactive fatty acids (disintegrations/min per 1 plasma) in arterial and venous plasma respectively.

(c) Gross (or net) utilization of NEFA (mmol/h per $\mathrm{kg}$ tissue) = gross (or net) fractional extraction $\times A \times P F$, where $P F$ is plasma flow ( $1 / \mathrm{h}$ per $\mathrm{kg}$ tissue).

(d) Production of NEFA $=$ gross utilization - net utilization.

(e) Maximum contribution of NEFA to tissue oxygen consumption

$$
=\frac{(A-V) \mathrm{NEFA} \times 24.5}{(A-V) \mathrm{O}_{2}},
$$

where $(A-V)$ NEFA represents the net arteriovenous difference for total NEFA and $(A-V) \mathrm{O}_{2}$ represents the corresponding blood oxygen arteriovenous difference. In both cases they are expressed in $\mu \mathrm{mol} / \mathrm{ml}$. To oxidize $1 \mu \mathrm{mol}$ of a 17 -carbon fatty acid, $24.5 \mu \mathrm{mol}$ oxygen are needed.

(f) Apparent proportion of $\mathrm{CO}_{2}$ from NEFA

$$
=\frac{\left({ }^{14} \mathrm{CO}_{2}\right)_{m}}{{ }^{14} \mathrm{C}-(\mathrm{NEFA})_{m} \times\left(\mathrm{CO}_{2}\right)_{A-V}},
$$

where $\left({ }^{14} \mathrm{CO}_{2}\right)_{m}$ is the average ${ }^{14} \mathrm{CO}_{2}$ released (disintegrations/min per $\mathrm{ml}$ ) over the whole period studied, that is, it is obtained from the area under the ${ }^{14} \mathrm{CO}_{2}$ arteriovenous-difference curve; ${ }^{14} \mathrm{C}$-(NEFA) $)_{m}$ is the corresponding average arterial SR (disintegrations/min per $\mu$ Atom $\mathrm{C})$ of the $\left[1{ }^{14} \mathrm{C}\right]$-labelled NEFA under study; and $\left(\mathrm{CO}_{2}\right)_{A-V}$ is the arteriovenous difference for $\mathrm{CO}_{2}$ across the tissue $(\mu \mathrm{mol} / \mathrm{ml})$. This calculation assumes that all carbons of the NEFA studied are equally susceptible to oxidation. The apparent proportion of $\mathrm{CO}_{2}$ derived from NEFA may be further corrected for indirect contributions from other metabolites. Thus, during the infusion of $\left[1-{ }^{14} \mathrm{C}\right]$-labelled NEFA, circulating ketone bodies formed in the liver from NEFA also became radio-labelled. Such ketones were taken up by muscle and must contribute to the ${ }^{14} \mathrm{CO}_{2}$ produced. The maximal fractional contribution of $\left[{ }^{14} \mathrm{C}\right]$-labelled ketones was estimated from the ratio (labelled ketone uptake):(labelled ketone uptake+labelled NEFA uptake). It is assumed that the SR of acetoacetate is identical with that of 3-hydroxybutyrate during the infusion of $\left[1-{ }^{14} \mathrm{C}\right]$-labelled NEFA and that ketone bodies and NEFA taken up are equally susceptible to oxidation in the tissue. During infusion of $\left[1{ }^{14} \mathrm{C}\right]$-labelled NEFA, circulating acetate also becomes labelled and the maximum contribution of $\left[{ }^{14} \mathrm{C}\right]$-labelled acetate to the production of ${ }^{14} \mathrm{CO}_{2}$ in muscle was estimated as for the contribution from ketones, with comparable assumptions.

(g) Fraction of utilized NEFA directly oxidized

$$
=\frac{\text { net output } \mathrm{CO}_{2} \times \text { fraction net output derived from NEFA }}{\text { gross utilization of NEFA }},
$$

both $\mathrm{CO}_{2}$ and NEFA being expressed as mAtom $\mathrm{C}$. 


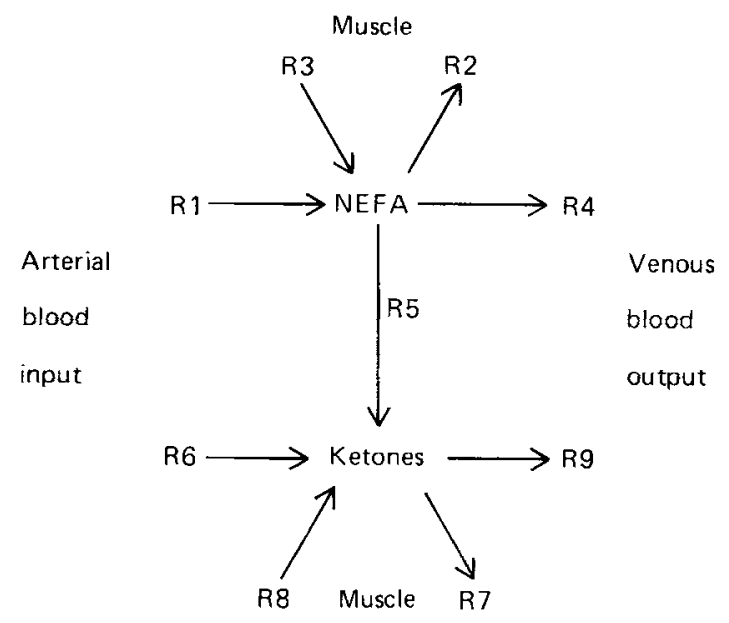

Fig. 1. Analysis of the interaction of non-esterified fatty acids (NEFA) and ketones. Results are based on four infusions of $\left[1-{ }^{14} \mathrm{C}\right]$-labelled NEFA, for which 3-hydroxybutyrate labelling of arterial inflow and venous outflow had been determined, and six infusions of $\left[\mathrm{U}-{ }^{14} \mathrm{C}\right]-\mathrm{D}(-) 3$-hydroxybutyrate (from results of Pethick \& Lindsay (1982c)). Rates are expressed as mAtom $\mathrm{C} / \mathrm{h}$ per $\mathrm{kg}$ muscle. It is assumed that following NEFA infusion, the specific radioactivity of total ketones is equal to that in 3-hydroxybutyrate and that there is no conversion of ketones to NEFA. The method of analysis is shown in the text. R 1 (arterial inflow of NEFA), $191 \pm 18 ; \mathrm{R} 2$ (non-ketogenic use of NEFA), $12 \pm 3$; R3 (release of NEFA within tissue) $14 \pm 4$; R4 (venous outflow of NEFA) $190 \pm 19$; R5 (rate of conversion of NEFA to ketones within tissue) $3 \pm 0 \cdot 8$; R6 (rate of arterial inflow of ketones) $176 \pm 37$; R7 (rate of ketone utilization in tissue) $18 \pm 1 \cdot 7 ; \mathbf{R} 8$ (rate of non-NEFA ketone production within tissue) $0.25 \pm 0.32 ; R 9$ (rate of venous outflow of ketones from tissue) $161 \pm 38$. $R 8$ is not significantly different from zero. $R 5 /(\mathbf{R} 5+\mathbf{R} 2)$ is the proportion of NEFA utilized which is used for ketogenesis.

\section{Compartmental analysis}

To estimate the extent of ketogenesis in the muscle of fasted pregnant ewes, a compartmental analysis has been applied using the model shown in Fig. 1. It is assumed that the intracellular SR of NEFA and ketones is the same as that of the appropriate venous SR and that 3-hydroxybutyrate and acetoacetate have the same SR. All rates are expressed as mAtom $\mathrm{C} / \mathrm{h}$ per $\mathrm{kg}$ muscle (for details of R1-R9, see Fig. 1 legend).

(1) R1 and R4 are obtained as the product of arterial or venous NEFA concentrations and plasma flow.

(2) R6 and R9 are obtained from results in an earlier study (Pethick \& Lindsay, 1982c) as the products of arterial or venous concentrations of ketones and blood flow.

(3) From results in the previous study (Pethick \& Lindsay, 1982c) consideration of isotope balance in the intracellular ketone compartment, when labelled ketone is infused gives $R 6 \times$ arterial $S R=(R 7+R 9) \times$ venous $S R$ from which $R 7$ can be calculated.

(4) From the present study, consideration of isotope balance in the intracellular ketone compartment following infusion of NEFA gives $(\mathbf{R} 6 \times$ arterial ketone $S R)+(R 5 \times$ venous NEFA SR $)=(R 7+R 9) \times$ venous ketone $S R$. Thus, $R 5$ may be calculated.

(5) From the present study, consideration of isotope balance in the intracellular NEFA compartment, following infusion of labelled NEFA gives (R1 $\times$ arterial NEFA $\mathrm{SR})=(\mathrm{R} 2+\mathrm{R} 5+\mathrm{R} 4) \times$ venous NEFA SR. Thus, $\mathrm{R} 2$ may be calculated.

(6) R3 may be calculated from $\mathrm{C}$ balance in the intracellular NEFA compartment: $\mathrm{R} 3=(\mathrm{R} 2+\mathrm{R} 4+\mathrm{R} 5)-\mathrm{R} 1$.

(7) R8 may be calculated from $\mathrm{C}$ balance in the intracellular ketone compartment: $\mathrm{R} 8=[\mathrm{R} 7+\mathrm{R} 9]-[\mathrm{R} 5+\mathrm{R} 6]$. 
Table 1. Composition of arterial plasma non-esterified fatty acids (NEFA) in pregnant ewes

(Mean values with their standard errors; no. of animals given in parentheses)

\begin{tabular}{|c|c|c|c|c|}
\hline & \multicolumn{4}{|c|}{ Nutritional state } \\
\hline & \multicolumn{2}{|c|}{ Fed (4) } & \multicolumn{2}{|c|}{ Fasted (8) } \\
\hline & Mean & SE & Mean & $\mathrm{SE}$ \\
\hline $\begin{array}{l}\text { Total NEFA (mM) } \\
\text { Individual fatty } \\
\text { acids (mmol/mol } \\
\text { total NEFA) }\end{array}$ & 0.84 & 0.07 & $1.59^{*}$ & $0 \cdot 20$ \\
\hline C $14: 0$ & 12 & 2 & 12 & 1 \\
\hline C 16:0 & 199 & 17 & 184 & 4 \\
\hline C 16:1 & 27 & 4 & $36^{*}$ & 2 \\
\hline C $18: 0$ & 323 & 14 & $256^{*}$ & 13 \\
\hline C $18: 1$ & 416 & 29 & $484^{*}$ & 15 \\
\hline C $18: 2$ & 28 & 5 & 22 & 2 \\
\hline
\end{tabular}

* Significantly different from fed; $P<0.05$ (Student's $t$ test).

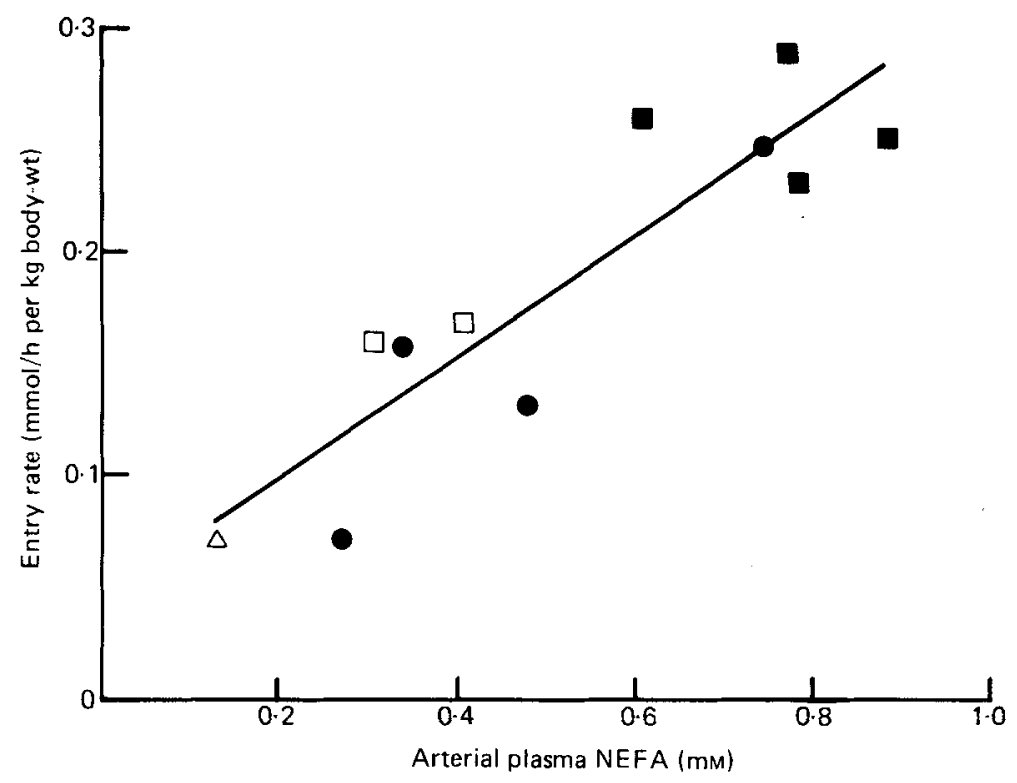

Fig. 2. Entry rate (mmol/h per $\mathrm{kg}$ body-weight) of individual non-esterified fatty acids (NEFA) in pregnant ewes. $(\triangle)$, Palmitic, fed; $(\odot)$, stearic, fasted; $(\square)$, oleic, fed; $(\square)$, oleic, fasted; $y=0 \cdot 27 x+0 \cdot 04$ $(r 0.9 ; P<0.001)$, where $x$ is the arterial concentration $(\mathrm{mM})$ of the particular $\left[{ }^{14} \mathrm{C}\right]$-labelled NEFA infused and $y$ is the entry rate ( $\mathrm{mmol} / \mathrm{h}$ per $\mathrm{kg}$ body-weight).

\section{RESULTS}

\section{Plasma composition}

Table 1 shows the arterial NEFA concentrations and the molar proportions of the individual fatty acids comprising total NEFA. Fasting pregnant ewes for 3-4 d induced a two-fold increase in total NEFA, significantly reduced the molar proportion of stearic acid 
Table 2. Some indices of non-esterified fatty acid (NEFA) metabolism in pregnant ewes

(Mean values with their standard errors; no. of animals in parentheses)

\begin{tabular}{|c|c|c|c|c|}
\hline & \multicolumn{4}{|c|}{ Nutritional state } \\
\hline & \multicolumn{2}{|c|}{ Fed (3) } & \multicolumn{2}{|c|}{ Fasted (8) } \\
\hline & Mean & SE & Mean & $\mathrm{SE}$ \\
\hline Entry rate (mmol/h per $\mathrm{kg}$ body-weight) & 0.44 & 0.02 & 0.55 & 0.07 \\
\hline Fractional contribution to $\mathrm{CO}_{2}$ output & 0.34 & 0.05 & 0.58 & 0.07 \\
\hline Fraction of entry rate oxidized & 0.46 & 0.06 & 0.59 & 0.03 \\
\hline Fraction of 3-hydroxybutyrate derived from NEFA & ND & - & 0.57 & $0.03^{*}$ \\
\hline Fraction of acetate derived from NEFA & ND & - & 0.41 & $0.08 \dagger$ \\
\hline
\end{tabular}

ND, not determined.

* Seven experiments

$\dagger$ Five experiments.

and increased the proportion of oleic acid. The sum of palmitic, stearic and oleic acids represented more than $90 \%$ of the total plasma NEFA in fed and fasted ewes. The concentration and SR of plasma NEFA remained fairly constant throughout the $\left[1-{ }^{14} \mathrm{C}\right]$-labelled NEFA infusion and infused NEFA SR was never less than 100 disintegrations $/ \mathrm{min}$ per $\mu \mathrm{mol}$ during infusion.

\section{Whole-animal entry rate and oxidation}

The entry rate of individual NEFA in these experiments was directly related to the corresponding circulating concentration (Fig. 2), a single equation being adequate for all the NEFA studied. This suggests that tracer NEFA were representative of total NEFA. Entry rates for total NEFA, determined on this basis are shown in Table 2.

The rate of appearance of ${ }^{14} \mathrm{CO}_{2}$ derived from $\left[{ }^{14} \mathrm{C}\right]$-labelled NEFA was rather sluggish. From the rate constants (obtained as described on p. 131) one may estimate that the SR of ${ }^{14} \mathrm{CO}_{2}$ after a $5 \mathrm{~h}$ infusion of $\left[{ }^{14} \mathrm{C}\right]$-labelled NEFA was approximately $50 \%$ of the calculated equilibrium value. This is in striking contrast to results we have obtained for the oxidation of many metabolites. We have found, for example, during infusion of $\left[{ }^{14} \mathrm{C}\right]$-labelled carbonate or $\left[{ }^{14} \mathrm{C}\right]$-labelled acetate that the $\mathrm{SR}$ after $5 \mathrm{~h}$ infusion is $98-99 \%$ of the steady-state value; even during infusion of $\left[{ }^{14} \mathrm{C}\right]$-labelled lactate or amino acids such as alanine, leucine or tyrosine the corresponding value is $80-90 \%$. During infusion of ketones however $\left(\left[{ }^{14} \mathrm{C}\right]\right.$-labelled 3-hydroxybutyrate or acetoacetate $)$ the corresponding value is about $75 \%$. As discussed later, conversion of NEFA to ketones may be a factor in the sluggish oxidation of NEFA.

Because of this slow approach to the steady-state value for $\mathrm{SR}$ of ${ }^{14} \mathrm{CO}_{2}$, there is potential for considerable error in the estimation of the contribution of NEFA to $\mathrm{CO}_{2}$ production. In practice this seems much less serious, since the calculated contribution of individual NEFA to respiratory $\mathrm{CO}_{2}$ correlated well with the circulating arterial concentration (see Fig. 3). Individual NEFA seem to be equally susceptible to oxidation and on this basis we have used the mean plasma NEFA $_{\text {SR }}$ to calculate total NEFA oxidation (Table 2).

The fraction of $\mathrm{D}(-) 3$-hydroxybutyrate derived from NEFA (Table 2 ) is probably a minimal estimate since it was not established that the SR of $D(-) 3$-hydroxybutyrate had attained a steady-state value during the NEFA infusion; this may also be true for the estimate of the fraction of acetate derived from NEFA. 


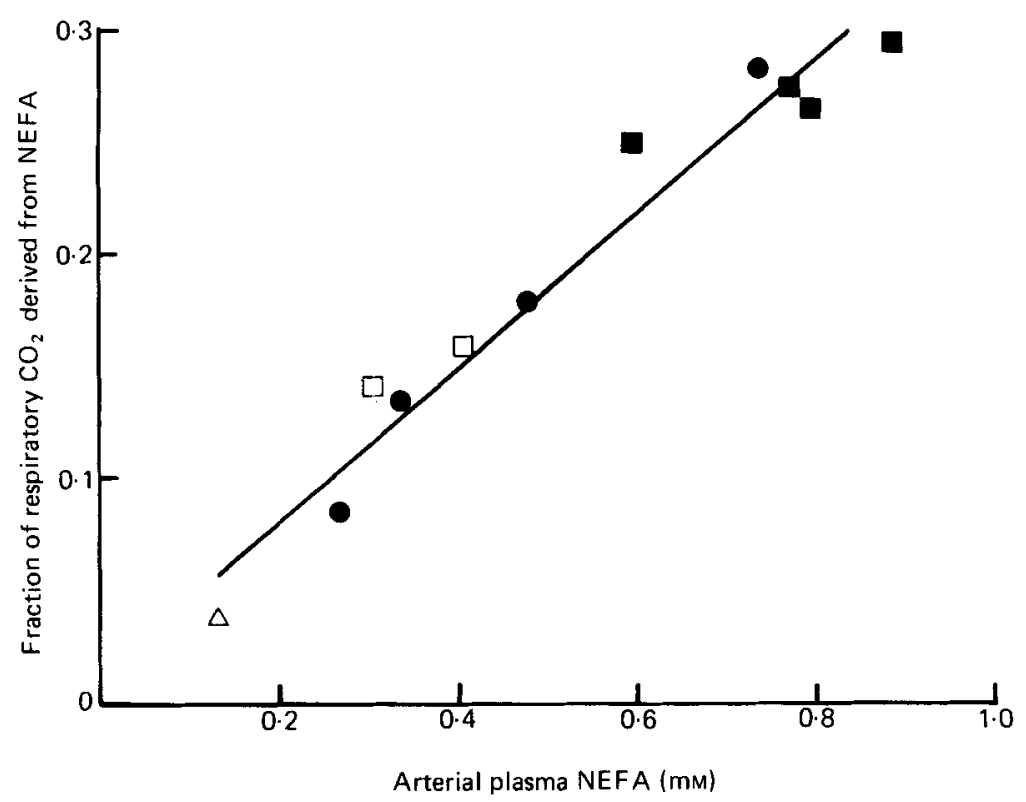

Fig. 3. Proportion of expired carbon dioxide derived from individual plasma non-esterified fatty acids (NEFA) in pregnant ewes. $(\triangle)$, Palmitic, fed; $(O)$, stearic, fasted; $(\square)$, oleic, fed; $(\square)$, oleic, fasted; $y=0.34 x+0.001(r 0.98 ; P<0.001)$, where $x$ is the arterial concentration (mM) of the particular $\left[{ }^{14} \mathrm{C}\right.$-labelled NEFA infused and $y$ is the fraction of respiratory carbon dioxide derived from the oxidation of this fatty acid.

\section{Tissue utilization and oxidation}

The findings are summarized in Table 3. Production and gross utilization were almost identical, net fractional extraction being almost zero. Net fractional extraction of the individual infused NEFA (not shown in Table 3) correlated well with the net fractional extraction of total NEFA $(r 0.93, n 11)$. It is, therefore, reasonable to suppose that the gross fractional extraction of the infused NEFA is indicative of that of total NEFA. This is supported by the relationship of gross utilization to arterial concentration (Fig. 4), the individual fatty acids fitting a common relationship.

In contrast, there was no significant gross or net utilization of plasma NEFA by the uterus, gross fractional extraction being (mean \pm SE) $0.011 \pm 0.013(n 3)$ and no significant release of ${ }^{14} \mathrm{CO}_{2}$ from this tissue.

Direct study of the oxidation of plasma NEFA by hind-limb muscle was made only in fasted pregnant ewes. Fig. 5 shows the pattern of ${ }^{14} \mathrm{CO}_{2}$ excretion by the hind-limb muscle during the infusion of $\left[1-{ }^{14} \mathrm{C}\right]$-labelled stearic acid; experiments employing $\left[1-{ }^{14} \mathrm{C}\right]$-labelled oleic acid gave similar results. Two features may be noted. First, there is an appreciable lag period before labelled $\mathrm{CO}_{2}$ is produced from the muscle and second, the peak $\left({ }^{14} \mathrm{CO}_{2}\right)_{A-V}$ difference frequently occurs after the end of the infusion. These observations suggest that in muscle there is rather slow equilibration between labelled and unlabelled $\mathrm{CO}_{2}$ and this may partly account for the finding that, as with acetate (Pethick et al. 1981) and ketones (Pethick \& Lindsay, $1982 c$ ), the equilibrium values for $\left({ }^{14} \mathrm{CO}_{2}\right)_{\mathrm{SR}}$ gave estimates consistently lower $(0.6-0 \cdot 7)$ than the area values. Only by using the latter technique was there shown to be a significant relationship between the concentration of an individual plasma NEFA and its fractional contribution to ${ }^{14} \mathrm{CO}_{2}$ production by hind-limb muscle (Fig. 6). Oleic and stearic acids seemed to be equally susceptible to oxidation by muscle. 
Table 3. Metabolism of non-esterified fatty acids (NEFA) by hind-limb muscle of pregnant ewes

(Mean values with their standard errors; no. of animals in parentheses)

\begin{tabular}{|c|c|c|c|c|}
\hline & \multicolumn{4}{|c|}{ Nutritional state } \\
\hline & \multicolumn{2}{|c|}{ Fed (3) } & \multicolumn{2}{|c|}{ Fasted (7) } \\
\hline & Mean & SE & Mean & SE \\
\hline Net fractional extraction of total NEFA & 0.01 & 0.07 & 0.01 & 0.03 \\
\hline Gross fractional extraction of infused NEFA & 0.12 & 0.02 & 0.08 & 0.01 \\
\hline $\begin{array}{l}\text { Maximum contribution of total NEFA taken up to tissue oxygen } \\
\text { consumption }\end{array}$ & 0.64 & 0.06 & 0.78 & $0 \cdot 15$ \\
\hline $\begin{array}{l}\text { Maximum contribution of total NEFA to } \mathrm{CO}_{2} \text { production } \\
\text { Ratio of uptakes }\end{array}$ & \multicolumn{2}{|c|}{ ND } & 0.54 & 0.08 \\
\hline$\frac{\left[{ }^{14} \mathrm{C}\right]-\text { ketone }}{\left[{ }^{14} \mathrm{C}\right]-\text { ketone }+\left[{ }^{14} \mathrm{C}\right]-\mathrm{NEFA}}$ & \multicolumn{2}{|c|}{ ND } & $0 \cdot 23$ & 0.02 \\
\hline$\frac{\left[{ }^{14} \mathrm{C}\right] \text {-acetate }}{\left[{ }^{14} \mathrm{C}\right] \text {-acetate }+\left[{ }^{14} \mathrm{C}\right]-\mathrm{NEFA}}$ & \multicolumn{2}{|c|}{ ND } & $0 \cdot 01$ & $0.01^{*}$ \\
\hline
\end{tabular}

ND, not determined.

* Four experiments.

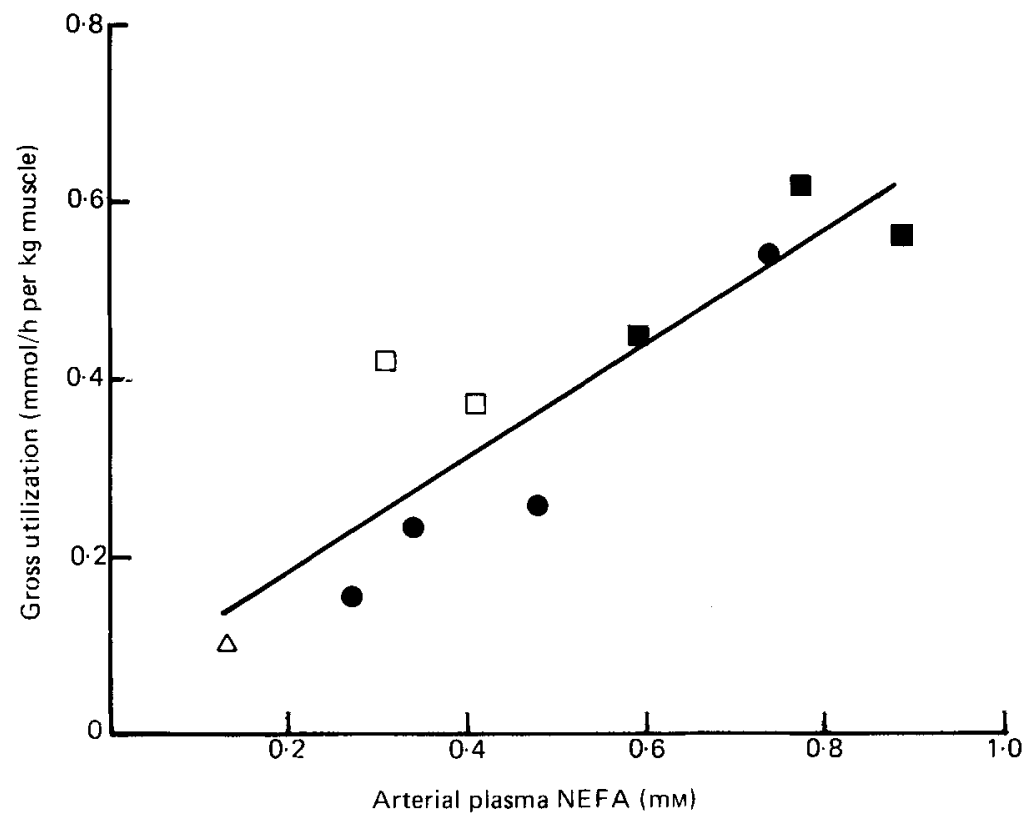

Fig. 4. Gross utilization ( $\mathrm{mmol} / \mathrm{h}$ per $\mathrm{kg}$ muscle) of individual non-esterified fatty acids (NEFA) by the muscle of pregnant ewes. $(\triangle)$, Palmitic, fed; (O) stearic, fasted; $(\square)$ oleic, fed; $(\square)$, oleic, fasted; $y=0.63 x+0.06(r 0.89 ; P<0.001)$, where $x$ is the arterial concentration (mM) of the particular $\left[{ }^{14} \mathrm{C}\right]$-labelled NEFA infused and $y$ is the corresponding gross utilization (mmol/h per $\mathrm{kg}$ muscle). 


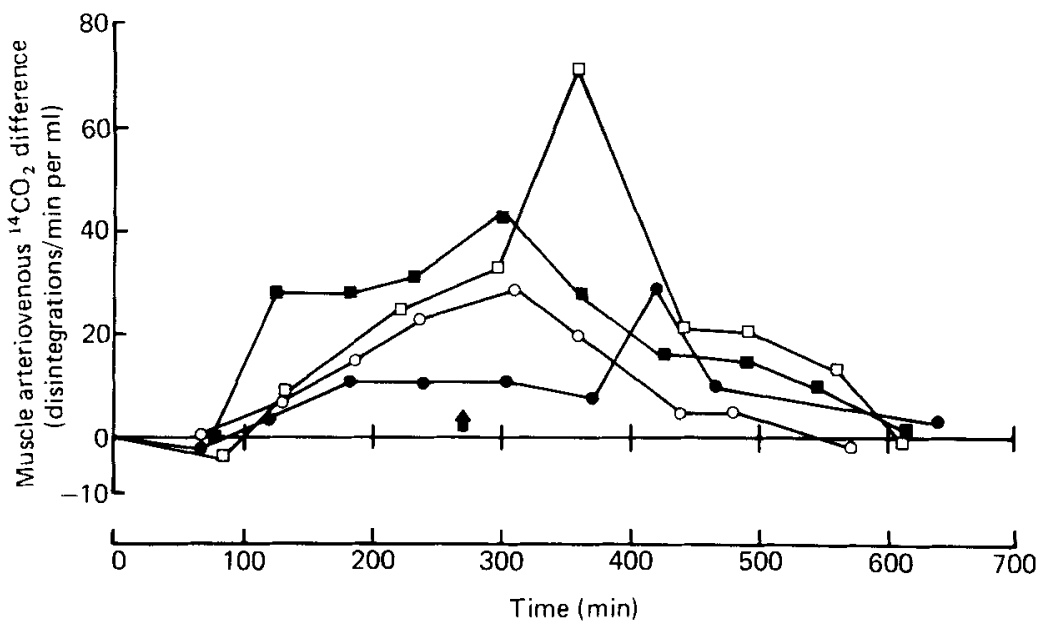

Fig. 5. Release of ${ }^{14} \mathrm{CO}_{2}$ by hind-limb muscle during and after infusion of $\left[1-{ }^{14} \mathrm{C}\right]$-stearic acid into fasted, pregnant ewes. Results are for four individual experiments $(O, O, \square, \square)$. Infusion of $\left[{ }^{14} \mathrm{Cl}-\right.$ labelled stearic acid was from time 0 to $\uparrow$.

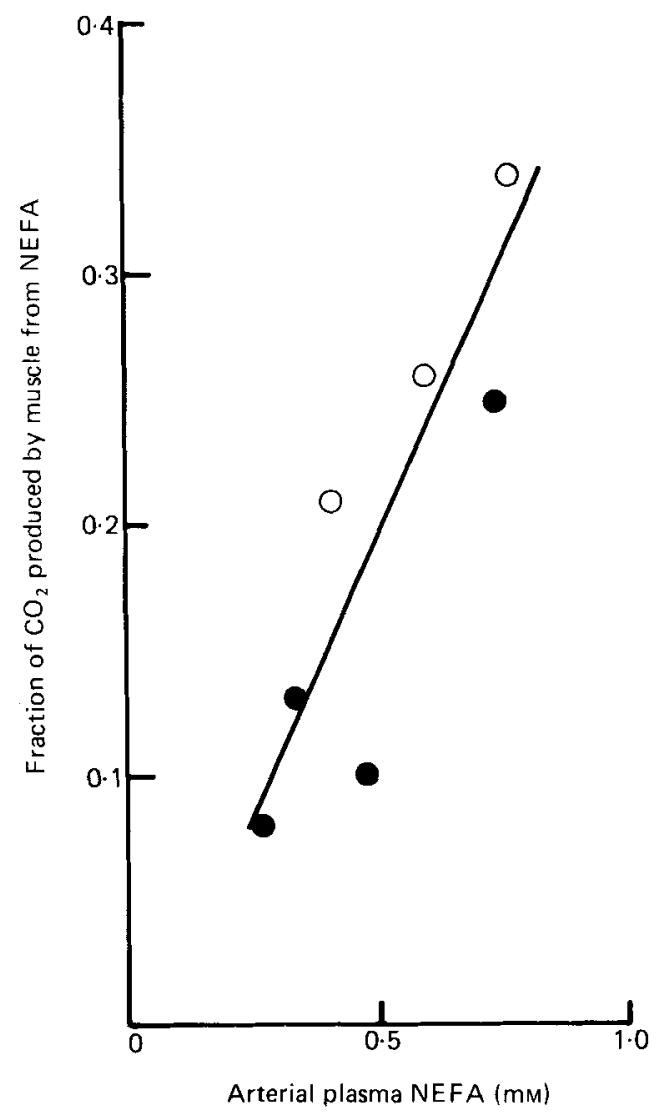

Fig. 6. Apparent contribution of individual non-esterified fatty acids (NEFA) to respiratory carbon dioxide in fasted, pregnant ewes. (O), stearic; $(O)$, oleic; $y=0.43 x-0.02(r 0.86 ; P<0.01)$, where $x$ is the arterial concentration (mM) of the particular $\left[{ }^{14} \mathrm{C}\right]$-labelled NEFA infused and $y$ is the fraction of the respiratory carbon dioxide apparently produced from this NEFA. 
Table 4. Utilization of glucose, lactate and acetate by the hind-limb muscle and uterus of fasted pregnant ewes

(Mean values with their standard errors; no. of animals in parentheses)

\begin{tabular}{|c|c|c|c|c|c|c|}
\hline & \multicolumn{6}{|c|}{ Metabolite } \\
\hline & \multicolumn{2}{|c|}{ Glucose } & \multicolumn{2}{|c|}{ Lactate } & \multicolumn{2}{|c|}{ Acetate } \\
\hline & Mean & SE & Mean & SE & Mean & SE \\
\hline Arterial blood concentration (mM) & $1 \cdot 41$ & $0.08(17)$ & 0.72 & $0 \cdot 04(17)$ & $0 \cdot 16$ & $0 \cdot 02(6)$ \\
\hline Muscle arteriovenous difference (mM) & $0 \cdot 11$ & $0.01(17)$ & -0.12 & $0.01(17)$ & 0.03 & $0.01(6)$ \\
\hline Uterine arteriovenous difference (mM) & $0 \cdot 25$ & $0.04(6)$ & $-0 \cdot 04$ & $0.01(6)$ & \multicolumn{2}{|c|}{ ND } \\
\hline Fractional contribution to muscle oxygen uptake & $0 \cdot 10$ & $0.01(17)$ & - & $\ldots$ & 0.03 & $0.003(6)$ \\
\hline Fractional contribution to uterine oxygen uptake & 0.70 & $0.08(6)$ & 一 & 一 & \multicolumn{2}{|c|}{ ND } \\
\hline
\end{tabular}

The contribution of a metabolite to oxygen consumption assumes complete oxidation of the metabolite. $1 \mathrm{~mol}$ glucose requires $6 \mathrm{~mol}$ oxygen and $1 \mathrm{~mol}$ acetate requires $2 \mathrm{~mol}$ oxygen. Results for glucose have been corrected for lactate output.

ND, not determined.

The SR of 3-hydroxybutyrate in muscle venous blood was either the same (three experiments) or greater (one experiment) than in arterial blood, consistent with some ketogenesis from NEFA in muscle. For acetate, muscle venous SR was higher than in arterial plasma in three of four experiments, consistent with NEFA also contributing to acetate production within muscle.

The utilization of glucose and acetate and production of lactate by the hind-limb muscle of fasted pregnant ewes is shown in Table 4. There was a substantial production of lactate by the hind-limb muscle ( $55 \%$ of the glucose utilization) whereas lactate production by the pregnant uterus represented only $8 \%$ of the glucose utilization. Glucose was thus potentially a significant source of energy for the pregnant uterus but only a minor source for muscle. Acetate made only a small contribution to the energy metabolism of muscle.

\section{DISCUSSION \\ Metabolism of individual NEFA}

This study has shown that the major NEFA in plasma are metabolized similarly in pregnant ewes. There is some evidence that stearic and linoleic acids may be metabolized at different rates by non-pregnant sheep (Annison et al. 1967; Lindsay \& Leat, 1977). Furthermore, Thompson et al. (1975) found that sheep liver did not utilize stearic acid. This is unlikely in fasted pregnant ewes since in the present study the percentage ketogenesis (which occurs primarily in the liver) from NEFA was similar whether results (mean \pm SE) from $\left[{ }^{14} \mathrm{C}\right]$-stearic $(53 \pm 6, n 3)$ or $\left[{ }^{14} \mathrm{C}\right]$-oleic $(59 \pm 6, n 4)$ acids were used. On the utilization of linoleic acid in pregnancy we have no information, but it provided only $2-3 \%$ of the total NEFA and in the following discussion it is assumed that the tracer NEFA used was representative of total NEFA.

\section{Magnitude of entry}

In fed and fasted pregnant ewes there was a large entry rate for NEFA which if oxidized would be sufficient to account for a large fraction of the total oxygen consumption suggesting, as has other work (Lindsay, 1973), that NEFA are an important fuel even in fed pregnant sheep. Since there is little difference in the utilization of individual fatty acids, the increase in C18:1 and decrease in the stearic fractions of NEFA associated with fasting must represent a change in the origin of the NEFA. In fed sheep NEFA will be in part 
derived from dietary fatty acids which are rich in stearic acid. Since, however, there is also a significant mobilization of depot fat, the increased proportion of oleic acid in fasting may be due to an increased contribution from subcutaneous depot fats, which tend to be richer in unsaturated fatty acids (Leat, 1978).

\section{NEFA oxidation by the whole animal}

The most likely explanation for the slow appearance of ${ }^{14} \mathrm{CO}_{2}$ from infused $\left[{ }^{14} \mathrm{C}\right]$-labelled NEFA is that it is a result of indirect catabolism of NEFA via ketones and acetate. The response seen in fed pregnant sheep, where the rate of appearance of ${ }^{14} \mathrm{CO}_{2}$ is neither as slow as seen in fasted pregnant sheep nor as prompt as with most metabolites, is not inconsistent with this since fed pregnant sheep have usually some ketonaemia. In starved sheep, indirect oxidation via acetate cannot be large. From the circulating blood acetate we observed $(0.2 \mathrm{~mm})$ and the relationship between this and the entry rate (Pethick \& Lindsay, $1982 b$ ), entry rate would be approximately $0.3 \mathrm{mmol} / \mathrm{h}$ per $\mathrm{kg}$ body-weight. Even if this flux were entirely derived from NEFA, oxidation would account for less than $5 \%$ of the NEFA oxidized. In contrast, a substantial part of NEFA is oxidized via ketones. The rate of total ketone production $(1 \mathrm{mmol} / \mathrm{h}$ per $\mathrm{kg}$ body-weight $)$ we found in fasted pregnant ewes (Pethick \& Lindsay, 1982c) would account for nearly half the entry rate and the rate of oxidation of the ketones suggests approximately half the NEFA oxidized occurred via ketone-body formation.

\section{Tissue utilization}

The gross extraction of NEFA by hind-limb muscle found in this study is 2-3 times less than that found for the sheep hindquarter (Bergman et al. 1971), ox hind-limb (Bell \& Thompson, 1979), human forearm (Dagenais et al. 1976) and anaesthetized dog hind-limb (Spitzer \& Hori, 1969). Nevertheless, the amount taken up is sufficient to make a substantial contribution to energy requirements. The direct contribution of NEFA to $\mathrm{CO}_{2}$ production is approximately $43 \%$. Since we showed earlier (Pethick \& Lindsay, 1982c) that 3hydroxybutyrate and acetoacetate can account for $40-50 \%$ of muscle $\mathrm{CO}_{2}$, ketones and NEFA can together account for $80-90 \%$ of muscle $\mathrm{CO}_{2}$.

Zierler (1976) and Dagenais et al. (1976) have suggested that there is an extended delay in NEFA oxidation due to intermediate participation of triacylglycerols. Bell \& Thompson (1979) found a similar delay in the ox hind-limb where only $3 \%$ of the utilized NEFA were promptly oxidized. In our study the pattern of $\mathrm{CO}_{2}$ released by hind-limb muscle was similar to that found during the infusion of other $\left[{ }^{14} \mathrm{C}\right]$-labelled metabolites (Pethick et al. 1981; Pethick \& Lindsay, 1982c). The difference may partly be due to the method of measuring oxidation. Dagenais et al. (1976) and Bell \& Thompson (1979) assumed a steady-state for ${ }^{14} \mathrm{CO}_{2}$ production during the infusion of $\left[{ }^{14} \mathrm{C}\right]$-labelled NEFA and this may lead to an underestimate of substrate oxidation (Lindsay \& Setchell, 1976). In addition, formation of any triacylglycerols would be less in our study since peripheral tissues would have been in a more catabolic state.

Nevertheless, some fraction of NEFA utilized by the hind-limb muscle must enter pathways other than direct oxidation to $\mathrm{CO}_{2}$. In previous work (Pethick \& Lindsay, 1982c) the fall in SR of ketone bodies across the hind-limb when $\left[{ }^{14} \mathrm{C}\right]$-labelled ketone bodies were infused suggested there may be some ketone body production at this site. The results in Fig. 1 are consistent with the possibility that NEFA may be ketogenic in sheep muscle. It has to be recognized, however, that this analysis is tentative since the SR of acetoacetate during NEFA infusion was not determined, and it may not be justifiable to suppose that there is no conversion of ketones to NEFA. Some NEFA is also used in muscle in the formation of acetate, but this would account for only approximately $3 \%$ of the NEFA taken up. 
Table 5. Fractional contribution of major metabolites to the respiratory carbon dioxide of fasted pregnant and fed and fasted non-pregnant sheep

\begin{tabular}{|c|c|c|c|}
\hline \multirow[b]{2}{*}{ Metabolite } & \multicolumn{2}{|c|}{ Non-pregnant* } & \multirow{2}{*}{$\begin{array}{l}\text { Pregnant, } \\
\text { fasted 3-4d }\end{array}$} \\
\hline & Fed & Fasted $20-30 \mathrm{~h}$ & \\
\hline Acetate & $0 \cdot 32$ & 0.22 & $0.05 \ddagger$ \\
\hline \multicolumn{4}{|l|}{ Propionate } \\
\hline Direct & 0.19 & 0.05 & 一 \\
\hline Via glucose & $0 \cdot 04$ & 0.02 & - \\
\hline $\begin{array}{l}\text { Glucose (not from } \\
\text { propionate) }\end{array}$ & 0.05 & 0.08 & $0.09 \S$ \\
\hline \multicolumn{4}{|l|}{ Butyrate } \\
\hline Direct & 0.09 & 0.04 & -- \\
\hline Via ketones & 0.08 & 0.01 & - \\
\hline \multicolumn{4}{|l|}{ NEFA } \\
\hline Direct & $0.02 \dagger$ & 0.13 & 0.30 \\
\hline Via ketones & 0.02 & 0.04 & 0.30 \\
\hline Sum & 0.81 & 0.59 & 0.74 \\
\hline
\end{tabular}

* Results for non-pregnant sheep are taken or calculated from Annison et al. (1967).

$\dagger$ Estimated assuming regression shown in Fig. 3 is valid for non-pregnant sheep.

$\ddagger$ From estimated acetate entry rate assuming complete oxidation.

$\S$ From Bergman et al. (1968).

\section{Pregnant uterus}

There was no evidence that in fasting the pregnant uterus uses NEFA. The accuracy of the measurements was such that NEFA could at best account for less than $10 \%$ of the oxygen consumption of uterus and contents. This finding is consistent with those of James et al. (1972) which suggested there was no net utilization of NEFA by the foetus. The pregnant uterus of these fasted ewes took up glucose sufficient to meet $70 \%$ of its oxygen requirements. Oxidation of 3-hydroxybutyrate could meet most of the remaining energy needs (Pethick \& Lindsay, 1982c).

\section{Pattern of energy utilization}

The fractional contribution of the various energy-yielding metabolites in fasted pregnant ewes compared with non-pregnant ewes is shown in Table 5. Some of the estimates are only approximate, but it is unlikely that the metabolites shown account for all the respiratory $\mathrm{CO}_{2}$. Amino acids and intracellular fatty acids not in isotopic equilibrium with NEFA probably constitute the remaining significant sources. The main features seen in the fasted pregnant ewe are a marked rise in the proportion of $\mathrm{CO}_{2}$ derived from NEFA-and the proportion of this that is indirectly oxidized-and a fall in the contribution of 'glycogenic' C. Most of this decrease, however, occurs from propionate, for tissues from the rumen. For other tissues there is little over-all change in the availability of glycogenic substrate. This masks marked changes in individual tissues, as is shown in Table 6. There is some reduction in glucose uptake by the gravid uterus in fasting since in fed pregnant sheep glucose uptake by the uterus is more than sufficient to meet total energy needs (Faichney et al. 1981). Nevertheless, glucose uptake is still large and constitutes a considerable demand on 'glycogenic' $\mathrm{C}$. In contrast, in the hind-limb muscle the energy source during fasting is almost entirely 'lipogenic'; even the glucose taken up is not necessarily oxidized. How much of the pattern is shifted is not yet clear since we do not know to what extent glucose taken up by muscle is oxidized (unpublished results (D. B. Lindsay) suggest much is not 
Table 6. Fractional contribution of major metabolites to the respiratory carbon dioxide produced in hind-limb muscle of non-pregnant fed and pregnant fasted sheep and in the uterus of fasted sheep

\begin{tabular}{lccc}
\hline Metabolite & $\begin{array}{c}\text { Muscle of } \\
\text { non-pregnant } \\
\text { fed sheep }\end{array}$ & $\begin{array}{c}\text { Muscle of } \\
\text { pregnant } \\
\text { fasted sheep }\end{array}$ & $\begin{array}{c}\text { Uterus of } \\
\text { pregnant } \\
\text { fasted sheep }\end{array}$ \\
\hline Glucose & 0.57 & 0.10 & 0.7 \\
Acetate & 0.30 & 0.03 & $0.03 \dagger$ \\
Ketones & 0.16 & 0.42 & 0.20 \\
Non-esterified fatty & $0.07^{*}$ & 0.42 & $<0.1$ \\
acids (total) & 1.1 & 0.97 & $0.93^{*}$ \\
\hline Sum & & 0.97 & 0 \\
\hline
\end{tabular}

Results in column 1 are taken from Pethick \& Lindsay (1982b) and Pethick et al. (1981).

* Estimated from regression relation of Fig. 6, assuming it is valid in non-pregnant animals.

$\uparrow$ Estimated from unpublished observations of D. B. Lindsay.

directly oxidized); nor how far the uptake of NEFA by muscle is affected by the presence of ketones (unpublished results (D. W. Pethick) suggest any effect is not large).

Zierler (1976) has suggested that muscle in non-ruminants relies mainly on NEFA as an energy source although the evidence for this has largely been obtained from studies in the post-absorptive state. In ruminants at least, our findings suggest that in most conditions NEFA are not the major energy source for muscle.

\section{REFERENCES}

Annison, E. F., Brown, R. E., Leng, R. A., Lindsay, D. B. \& West, C. E. (1967). Biochem. J. $104,135$.

Bell, A. W. \& Thompson, G. E. (1979). Am. J. Physiol. 237, E309.

Bergman, E. N., Havel, R. J., Wolfe, B. M. \& Bohmer, T. (1971). J. clin. Invest. 50, 1831.

Bergman, E. N., Starr, D. J. \& Reulein, S. S. (1968). Am. J. Physiol. 215, 874.

Blaxter, K. L. (1962). The Energy Metabolism of Ruminants. London: Hutchinson, Scientific \& Technical.

Dagenais, G. R., Tancredi, R. G. \& Zierler, K. L. (1976). J. clin. Invest. 58, 421.

De Vries, G. H., Mamunes, P., Miller, C. D. \& Hayward, D. M. (1976). Analyt. Biochem. $70,156$.

Dole, V. P. (1956). J. clin. Invest. 35, 150.

Faichney, G. J., Barker, P. J., Setchell, B. P. \& Lindsay, D. B. (1981). Q. Jl. expl. Physiol. 66, 195.

Friedberg, S. J., Klein, R. F., Trout, D. L., Bogdanofi, M. D. \& Estes, E. H. (1960). J. clin. Invest. 39, 1511.

Havel, R. J., Pernow, B. \& Jones, N. L. (1967). J. appl. Physiol. 23, 90.

Hinks, N. T., Mills, S. C. \& Setchell, B. P. (1966). Analyt. Biochem. 17, 551.

James, E. J., Raye, J. R., Gresham, E. L., Makowski, E. L., Meschia, G. \& Battaglia, F. C. (1972). Pediatrics, Springfield 50, 361 .

Leat, W. M. F. (1978). In Patterns of Growth and Development in Cattle, p. 231 [H. de Boer and J. Martin, editors]. The Hague and London: Martinus Nijhoff for the Commission of European Communities.

Leat, W. M. F. \& Ford, E. J. H. (1966). Biochem. J. 101, 317.

Lindsay, D. B. (1973). In Production Diseases in Farm Animals, p. 107 [J. M. Payne, K. G. Hibitt and B. F. Sansom, editors]. London: Bailliere Tindall.

Lindsay, D. B. (1975). Proc. Nutr. Soc. 34, 241.

Lindsay, D. B. \& Leat, W. M. F. (1977). J. agric Sci., Camb. 89, 215.

Lindsay, D. B. \& Setchell, B. P. (1976). J. Physiol., Lond. 259, 801.

Neill, A. R., Grime, D. W., Snoswell, A. M., Northrop, A. J., Lindsay, D. B. \& Dawson, R. M. C. (1979). Biochem. J. 180, 559.

Pethick, D. W. \& Lindsay, D. B. (1982a). Proc. Aust. Nutr. Soc. 6, 105.

Pethick, D. W. \& Lindsay, D. B. (1982b). Br. J. Nutr. 48, 317.

Pethick, D. W. \& Lindsay, D. B. (1982c). Br. J. Nutr. 48, 549.

Pethick, D. W., Lindsay, D. B., Barker, P. J. \& Northrop, A. J. (1981). Br. J. Nutr. 46, 97. 
Snedecor, G. W. \& Cochran, W. G. (1967). In Statistical Methods, 6th ed., p. 447. Ames, Iowa : Iowa State College Press.

Spitzer, J. J. \& Gold, M. (1964). Am. J. Physiol. 206, 159.

Spitzer, J. J. \& Hori, S. (1969). Proc. Soc. exptl Biol. Med. 131, 555.

Thompson, G. E., Gardner, J. W. \& Bell, A. W. (1975). Q. Jl. exptl Physiol. 60, 107.

Zierler, K. L. (1976). Circulation Res. 38, 459. 